\title{
PENGELOLAAN HUTAN BERSAMA MASYARAKAT DITINJAU DARI PERSPEKTIF ASSETS BASED COMMUNITY DEVELOPMENT
}

Oleh:

Nisa Nimah Utami

\begin{abstract}
This research analyzed the "Collaborative Forest Management (CBFM) through community development activities from the perspective of Asset Based Commmunity Development. The study was conducted in the Pulosari Village, Pangalengan Sub-district, South Bandung District". The purposes of this study were to describe the implementation of collaborative forest management and to describe the utilization of Asset Based namely human, social, physical, financial, and environmental capital in the project

The study utilized qualitative research method. Data were obtained through indepth interviews from the personal represented the forest village community, the cooperative forest farmer groups. The study found that all stage of socialization, dialogue, negortiation, legal aspect, implementation, monitoring and evaluation, continue planning have been conducted. Similarly, the collaborative forest management through community development activities had been implemented according to Asset Based Community Development. The human, physical, social, financial, environmental capital had been utilized accordingly. However, lack of member participation and the lack of quality of human resources were not addressed properly.

The study recommended the necessity to increase the capacity of the cooperative of forest village communities in order to address problems in the community development activities in the village Pulosari. This included the improvement of knowledge, attitudes and skill of the members so that they can have greater partipation and the improvement of communication strategies with the stakeholder. These efforts are expected to increase the success of CBFM in community development activities as well as optimal utilization of assets.
\end{abstract}

Keywords: Collaborative Forest Management, Assets Based Community Development, the community development activities

\begin{abstract}
ABSTRAK
Penelitian ini menganalisa mengenai Pengelolaan Hutan Bersama Masyarakat (PHBM) melalui kegiatan pembinaan masyarakat ditinjau dari perspektif Asset Based Commmunity Development. Penelitian ini dilaksanakan di Desa Pulosari Kecamatan Pangalengan Kabupaten Bandung Selatan. Tujuan dari penelitian ini adalah untuk menggambarkan pelaksanaan PHBM dan pemanfaatan aset yaitu kapital manusia, kapital sosial, kapital fisik, kapital keuangan, dan kapital lingkungan dalam suatu program.

Metode penelitian yang digunakan adalah metode penelitian kualitatif. Data yang diperoleh melalui wawancara mendalam terhadap perwakilan masyarakat desa hutan diantaranya Lembaga Masyarakat Desa Hutan, Kelompok Tani Hutan, Koperasi, dan Perum Perhutani. Penelitian ini menemukan bahwa semua tahapan dalam pembinaan masyarakat berupa sosialisasi, dialog, negosiasi, aspek legal, pelaksanaan, monitoring dan evaluasi serta rencana tindak lanjut telah dilaksanakan. Demikian pula dengan PHBM melalui kegiatan pembinaan masyarakat telah sesuai dilaksanakan sesuai pengembangan masyarakat berbasis aset. Dimana kapital manusia, sosial, fisik, keuangan dan lingkungan telah dimanfaatkan pada setiap tahapan pembinaan masyarakat desa
\end{abstract}


hutan. Adapun kelemahan berupa kurangnya partisipasi secara aktif dari anggota dan rendahnya kualitas sumber daya manusia belum ditangani secara baik.

Penelitian ini merekomendasikan perlunya upaya peningkatan kapasitas koperasi masyarakat desa hutan untuk mengatasi masalah dalam kegiatan pembinaan masyarakat desa hutan di desa Pulosari. Hal ini termasuk peningkatan pengetahuan, sikap, dan keterampilan dari para anggota kelompok tani hutan sehingga mereka dapat memiliki tingkat partisipasi yang tinggi dan peningkatan strategi komunikasi antar para pemangku kepentingan. Upaya ini diharapkan dapat meningkatkan keberhasilan PHBM dalam kegiatan pembinaan masyarakat desa hutan serta pemanfaatan keseluruhan aset secara optimal.

Kata Kunci: Pengelolaan Hutan Bersama Masyarakat, Asset Based Commmunity Development, Pembinaan Masyarakat Desa Hutan

\section{PENDAHULUAN}

Indonesia merupakan salah satu negara yang dikaruniai dengan sumberdaya alam yang berlimpah sebagai sumber kehidupan salah satunya adalah hutan. Keberadaan hutan memiliki potensi bagi pemenuhan kepentingan sosial, ekonomi dan lingkungan melalui kegiatan pengelolaan dan pemanfaatannya. Dengan adanya kegiatan pengelolaan dan pemanfaatan sumberdaya hutan dapat memberikan kontribusi terhadap kesejahteraan masyarakat desa hutan. Sumberdaya alam yang besar tentu perlu dikelola dengan baik dan bertanggung jawab guna menjamin keberlanjutan pembangunan generasi.

Hutan sungguh kaya dengan beragam potensinya. Mulai hasil kayu hutan, hasil hutan bukan kayu, hingga jasajasa lingkungan. Telah menjadi tradisi selama ratusan tahun, hutan menjadi sumber kehidupan bagi masyarakat yang hidup di dalam dan di sekitarnya. Berdasarkan identifikasi desa di kawasan hutan tahun 2006, tercatat sebanyak 31.864 desa yang tersebar di 15 provinsi. Dari 31.864 desa yang tercatat, terdapat 16.760 desa yang berada di dalam kawasan hutan $(52,60 \%)$ sedangkan sisanya $(47,40 \%)$ berada diluar kawasan hutan (Media Persaki vol.12 2009:20).

Berdasarkan uraian di atas masyarakat desa hutan (MDH) dikaruniai kelimpahan sumberdaya hutan. Dengan kelimpahan sumberdaya seharusnya MDH memiliki tingkat kesejahteraan yang tinggi. Namun kenyataaanya, masyarakat yang hidup di sekitar dan di dalam kawasan hutan pada umumnya merupakan masyarakat yang tertinggal, dan kondisi sosial ekonomi masyarakat ini umumnya juga masih rendah, serta masyarakat cenderung malakukan perambahan kawasan hutan. Hal ini diperkuat oleh data Badan Pusat Statistik tahun 2009, jumlah penduduk miskin tercatat 52,53 juta. Jumlah penduduk Indonesia yang tinggal di sekitar kawasan hutan yang kehidupannya bergantung pada sumber daya hutan sekitar 48,8 juta orang dimana 10,2 juta orang diantaranya tergolong miskin. 1 
Luas hutan di Pulau Jawa mencapai 13,4 juta hektar (Badan Planologi Kehutanan,2007) dengan jumlah penduduk sekitar 128.738.000 jiwa (BPS, 2004). Sebagian besar wilayah hutan tersebut dikelilingi oleh daerah pedesaan. Jumlah penduduk yang besar telah meningkatkan tekanan penduduk dan perambahan kawasan hutan terutama pada wilayah pedesaan yang berada di sekitar hutan. Masih tingginya angka pengangguran yang berdasarkan data BPS (2004) mencapai 10,2 juta jiwa. Pengangguran merupakan kurangnya jumlah pekerjaan dibandingkan dengan tenaga kerja yang tersedia. Tekanan jumlah penduduk dan terbatasnya lapangan pekerjaan menimbulkan efek negatif terhadap kelestarian dan fungsi hutan seperti pengembalaan liar, pencurian kayu, maupun pembukaan lahan hutan untuk usaha pertanian.

Disamping kondisi masyarakat desa hutan masih banyak yang miskin, pengangguran dan maraknya tindakan perambahan hutan tyang dilakukan oleh masyarakat desa hutan menunjukan masih adanya ketidakpedulian masyarakat akan kelestarian fungsi hutan dan lingkungan hidup. Upaya perlindungan dan pengamanan hutan memerlukan partisipasi dan tanggung jawab bersama antara pemerintah dan masyarakat. Upaya ini dilakukan untuk menjaga kelestarian hutan yang memberikan manfaat bagi masyarakat pada umumnya dan masyarakat sekitar hutan pada khususnya.
Hal ini diperkuat oleh data tahun 2003 menunjukkan bahwa perambahan mencapai luas kawasan 15.397,49 hektar dengan melibatkan sejumlah 34.740 KK. Tingginya jumlah penduduk dan suburnya lahan di wilayah KPH Bandung Selatan merupakan penyebab terjadinya perambahan hutan. Wilayah yang paling banyak dijarah pada kawasan hutan di BKPH Pangalengan yang diikuti secara berturut-turut oleh BKPH Ciparay dan BKPH Banjaran (Muhamad Komarudin, 2008:35)

Merespon fenomena tersebut, Perum Perhutani sebagai pengelola hutan produksi di Pulau Jawa dan Madura mengeluarkan keputusan Nomor 136/Kpts/Dir/2001 tentang pengelolaan hutan bersama masyarakat. PHBM adalah suatu sistem pengelolaan sumberdaya hutan yang dilakukan bersamasama antara Perum Perhutani dan masyarakat desa, atau Perum Perhutani dan Masyarakat Desa Hutan (MDH) dengan pihak yang berkepentingan (stakeholder) berdasarkan prinsip berbagi, sehingga kepentingan bersama untuk mencapai keberlanjutan fungsi dan manfaat sumberdaya hutan dapat diwujudkan secara optimal dan proporsional. (Keputusan Direksi Perum Perhutani Nomor 682/KPTS/DIR/2009).

Adapun hasil dari PHBM yaitu peningkatan indeks pembangunan manusia yang menggambarkan tingkat kesejahteraan masyararakat desa hutan dengan indikator peningkatan daya beli, peningkatan tingkat 
pendidikan dan peningkatan derajat kesehatan. Untuk mencapai sasaran tersebut telah disusun program PHBM berupa perencanaan PHBM, pembinaan SDM, pembinaan $\mathrm{SDH}$, pengelolaan produksi, industri \& pemasaran, dukungan keuangan, dan pengamanan hutan.

Berdasarkan uraian di atas PHBM dimaksudkan untuk mengembangkan kapasitas dengan memberikan akses kepada masyarakat desa hutan dalam memanfaatkan kawasan hutan guna menjamin ketersediaan lapangan kerja bagi masyarakat desa hutan untuk memecahkan persoalan ekonomi dan sosial yang terjadi di masyarakat. Dengan adanya PHBM diharapkan dapat meningkatkan kesejahteraan masyarakat desa hutan melalui pemanfaatan sumber daya hutan secara optimal dengan tetap menjaga kelestarian fungsi hutan dan lingkungan hidup.

Hal ini dituangkan dalam UndangUndang Dasar Republik Indonesia memberi amanat dalam pasal 33, bahwa bumi, air, dan kekayaan yang terkandung didalamnya adalah pokok-pokok atau sendi kemakmuran rakyat, sehingga harus dikuasai oleh negara untuk di gunakan sebesar-besarnya demi kemakmuran rakyat. Oleh karena itu, pengelolaan sumberdaya hutan tidak dapat meniadakan interaksi antara masyarakat dengan hutan.

Total desa hutan di Pulau Jawa dan Madura, tidak kurang dari 5.403 desa hutan berada di sekitar kawasan hutan Perum Perhutani, dimana 111 desa hutan berada di KPH Bandung Selatan, dan 12 desa hutan berada di BKPH Pangalengan, salah satu yaitu desa Pulosari. Desa Pulosari merupakan sebuah desa hutan di BKPH Pangalengan KPH Bandung Selatan berlangsung aktivitas budidaya kopi arabika dalam skala besar. Dimana masyarakat diajak untuk melaksanakan budidaya kopi. Dari hasil yang dipeleh diharapkan dapat meningkatkan taraf hidup mereka (terwujudnya fungsi hutan untuk meningkatkan kesejahteraan masyarakat). (Wawan Setiawan, 2008:14)

Menurut Rubin (2000), pengembangan aset merupakan inti pengembangan masyarakat. Keterampilan dan sumber daya yang diperoleh dapat membangun kepercayaan diri dan mengembalikan semangat komunitas. Semakin meluasnya kesenjangan diantara anggota masyarakat, Briggs menyatakan bahwa kegiatan yang dilakukan yaitu pengembangan akses permodalan yang memfasilitasi peningkatan pendapatan antara lain penciptaan lapangan kerja, hal ini menunjukan

praktik pengembangan tersebut berupa membangun aset/potensi masyarakat. ${ }^{3}$

Praktik pengembangan masyarakat banyak dilakukan di Indonesia oleh pemerintah, swasta maupun LSM. Praktik 
pengembangan masyarakat dapat dilakukan dalam berbagai sektor pertanian, kehutanan, perdagangan, industri, pendidikan dan sebagainya. Sasatrawan Manullang (dalam Jim Ife: 2008) mengatakan bahwa label "pengembangan masyarakat" tidak selalu menjamin bahwa kegiatan yang dilakukan benar-benar pro masyarakat

Undang-Undang Nomor 22 Tahun 1999 dan Undang-Undang Nomor 32 Tahun 2004 tentang Pemerintahan Daerah, telah memberikan kesempatan yang lebih luas kepada pemerintah di tingkat lokal untuk lebih inovatif dalam pembangunan di daerahnya masing-masing. Dengan demikian terbuka peluang bagi warga untuk turut serta berpartisipasi dalam proses pembangunan yang dituangkan ke dalam program- program pengembangan masyarakat

Sebagai contoh fenomena tersebut dapat dilihat dari munculnya beberapa program pengembangan masyarakat seperti Jaring Pengaman Sosial (JPS), Program Penganggulangan Kemiskinan di Perkotaan (P2KP), Beras Miskin (Raskin), Bantuan Langsung Tunai (BLT), dan Pengelolaan Hutan Bersama Masyarakat (PHBM). Pada umumnya program pengembangan masyarakat yang telah dilaksanakan bersifat topdown, yaitu kebijakan yang dilaksanakan berasal dari pemerintah, hanya PHBM melalui Lembaga Masyarakat Desa Hutan (LMDH) yang dalam melaksanakan program-program kegiatannya didasarkan atas inisiatif dan prakarsa dari masyarakat jadi bersifat bottom up. 4

Dalam Gary Paul Green (2002:3)

\section{Asset Based Community Development} memiliki beragam rangkaian tujuan, mulai dari memecahkan masalah lokal, mengatasi kesenjangan, serta meningkatkan potensi individu, dan membangun rasa kebersamaan. Konsep Asset Based Community Development merupakan metode yang bertujuan untuk memanfaatkan kekuatan yang ada didalam masyarakat sebagai sarana untuk pengembangan berkelanjutan yang didalamnya terdapat proses pengembangan untuk melihat potensi apa saja yang dimiliki masyarakat. Gary Paul Green (2002) menyatakan ada lima konsep utama pengembangan masyarakat berbasis aset yaitu kapital manusia, kapital sosial, kapital fisik, kapital pendapatan, kapital lingkungan.

Tujuan dari pengembangan masyarakat berbasis aset adalah untuk memberikan harapan dalam penanggulangan kemiskinan secara berkelanjutan, dimana pada awalnya masyarakat miskin kemudian keluar dari masalah tersebut dan menjadi mandiri melalui potensi yang ada di masyarakat yaitu dengan memanfaatkan kapital-kapital yang ada di masyarakat

Secara umum dari beberapa variasi mengenai konsep pengembangan masyarakat berbasis aset, maka Gary Paul Green (2002) dalam Asset Based Community development, 
menguraikan konsep pengembangan masyarakat berbasis aset yaitu kapital manusia, kapital sosial, kapital fisik, kapital pendapatan, kapital lingkungan.

Pertama yaitu kapital manusia (Human Capital). Ini adalah kapital masyarakat dilihat dari karakteristik individu, apakah individu tersebut memiliki kemampuan dan keterampilan dalam bekerja. Hal tersebut sangat berpengaruh pada produktivitas mereka. Untuk memiliki kapital manusia yang baik salah satunya yaitu membangun kemampuan individu dengan meningkatkan mutu pendidikan, kesehatan, dan pengalaman pekerjaan.

Kedua yaitu Kapital Sosial (Social Capital). Ini adalah kapital masyarakat dilihat dari kemampuan sekelompok individu yang melibatkan diri dalam suatu jaringan hubungan sosial seperti lembaga atau organisasi. Selain itu kapital sosial melihat potensi kelompok dan pola-pola hubungan antar individu dalam suatu kelompok yang didalamnya terdapat nilai-nilai, norma dan kepercayaan antar sesama anggota kelompok.

Ketiga yaitu Kapital Fisik (Physical Capital). Green dab Haines (2002:113) melihat dua kelompok utama dari modal fisik adalah bangunan dan infrastruktur. Bangunanyang dimaksud disini adalah rumah, pertokoan, perkantoran, gedung perniagaan, dan lain-lain. Sedangkan infrastruktur dapat berupa jalan raya, jembatan, jalan kerata api, sarana pembuangan limbah, sarana air bersih dan lain-lain.

Keempat yaitu Kapital Keuangan (Financial Capital) ini adalah kapital masyarakat dilihat dari uang, kapital, seperti apa yang mereka butuhkan untuk membuat produk atau menyediakan yaitu perbankan investasi, dll. Kebanyakan pasar kredit merespon kebutuhan masyarakat miskin karena pada umumnya mereka kurang memiliki akses ke kapital keuangan.

Kelima yaitu Kapital Lingkungan (Environmental Capital) ini adalah kapital masyarakat dilihat dari aspek dasar masyarakat sumber daya alam: udara, air, tanah, flora dan fauna dan sumber daya alam memiliki nilai penggunaan langsung.

Implementasi program pengembangan masyarakat masih belum dilakukan perpaduan dengan kapital manusia, sosial, fisik, keuangan dan lingkungan. Dalam penelitian ini praktik pengembangan masyarakat yang dilakukan Perum Perhutani dengan melibatkan peran serta masyarakat desa hutan melalui kegiatan budidaya kopi akan dikaji berdasarkan proses pembinaan masyarakat ditinjau dari perspektif Asset Based Community development yang dikemukakan oleh Gary Paul Green.

Peran serta masyarakat akan sangat berpengaruh pada keberhasilan program pengembangan masyarakat. Salah satunya ditentukan oleh pengakuan serta peningkatan 
hak dan kewajiban unt;'uk berpartisipasi (Jim Ife\& Frank Tesoriero, 2008). Berdasarkan kerangka berfikir diatas, mam ka dapat dikatakan bahwa pengembangan masyarakat sebagai sebuah strategi untuk membuka peluang kepada masyarakat sekitar hutan mampu mandiri dan dapat meningkatkan kesejahteraannya

Pengelolaan hutan bersama masyarakat telah memberikan angin segar bagi peningkatan kesejahteraan masyarakat desa hutan, lalu sejauh mana program ini memberikan kontribusi bagi kesejahteraan masyarakat desa hutan. Namun demikian masih perlu dipertanyakan apakah program tersebut benar-benar sesuai kondisi masyarakat sekitar kawasan hutan atau ini hanya lip service.

Berdasarkan latar belakang tersebut, maka perlu dilakukan penelitian tentang PHBM melalui kegiatan pembinaan masyarakat di BKPH Pangalengan, KPH Bandung Selatan, Perum Perhutani Unit III Jawa Barat-Banten ditinjau dari perspektif Asset Based Community Development, dengan mengajukan pertanyaan pokok penelitian: "Bagaimana Pengelolaan Hutan Bersama Masyarakat ditinjau dari perspektif Asset Based Community Development?"

\section{METODE PENELITIAN}

Metode penelitian yang digunakan dalam penelitisn ini adalah metode penelitian kualitatif. Daslam pendekatan kualitatif, penelitian didesain tidak selalu untuk mencari sebab akibat dari suatu gejala yang terjadi, nmun lebih berupaya memahami situasi tertentu. Penelitian kualitatif merupakan metode-metode untuk mengeksplorasi dan memahami makna yang oleh sejumlah individu atau sekelompok orang dianggap berasal dari masalah sosial atau kemanusiaan (Creswell, 2010:4)

Dari pernyataan di atas bahwa penelitian kualitatif merupakan suatu penelitian yang dimaksudkan untuk memahami fenomena yang dialami oleh subjek penelitian secara holistik dan dengan cara deskripsi dalam bentuk kata-kata dan bahasa, pada suatu konteks yang alamiah dengan berbagai metode alamiah. Satori dan Komariah menyatakan bahwa:

"Penelitian kualitatif adalah suatu pendekatan penelitian yang mengungkap situasi sosial tertentu dengan mendeskripsikan kenyataan secara benar, dibentuk oleh katakata berdasarkan tehnik pengumpulan dan analisis data yang relevan yang diperoleh dari situasi alamiah.”(Satori; Komariah, 2010:25)

Penelitian kualitatif yang dimaksudkan oleh pendapat ahli di atas tidak hanya sebagai upaya mendeskripsikan data tetapi deskripsi tersebut hasil dari pengumpulan data dan analisis data. Selanjutnya Bogdan dan Taylor (1975:5) yang dikutip Moleong mendefinisikan: Metodologi kualitatif sebagai prosedur penelitian yang menghasilkan data deskriptif 
berupa kata-kata tertulis atau lisan dari orangorang dan perilaku yang dapat diamati. (Moleong, 2007:6)

Berdasarkan pendapat para ahli di atas bahwa penelitian kualitatif merupakan penelitian yang menafsirkan fenomena yang terjadi secara alamiah yang memiliki karakteristik tertentu. Penelitian kualitatif mempuanyai karakteristik seperti yang dikemukakan Bogdan dan Biklen (!982:2729) yang dikutip Satori dan Komariah yaitu:

\section{Intensive, long term participation in} field setting

2. Careful recording of what happens in the setting by writing notes and interview notes by collecting other kinds of documentary evidencel

3. Analysis reflection on the documentary records obtained in the field

4. Reporting the results by means of derailed descriptions, direcr quotes from interview, and interpretative commentary.(Satori;Komariah, 2010:26)

Berdasarkan uraian di atas metode penelitian kualitatif dilakukan secara intensif, peneliti ikut berpartisipasi dalam jangka waktu tertentu dilapangan, mencatat secara hati-hati apa yang terjadi, melakukan analisis reflektif terhadap berbagai dokumen yang ditemukan di lapangan dan membuat laporan penelitian secara detail. Penelitian ini bertujuan untuk mendeskripsikan, mencatat, menganalisa Mengenai PHBM melalu kegiatan pembinaan masyarakat desa hutan yang dilakukan BKPH Pangalengan, Perum
Perhutani unit III Jawa Barat terhadap masyarakat desa hutan di Desa Pulosari.

Data yang dibutuhkan dalam penelitian ini meliputi fakta-fakta tentang pengelolaan hutan bersama masyarakat melalui kegiatan pembinaan masyarakat desa hutan di desa Pulosari. Terutama pihak-pihak yang terlibat dalam praktik pengembangan masyarakat dimaksud. Oleh karena itu, diperlukan rincian data yang dikumpulkan berupa data primer maupun data sekunder. Yang dimaksud data primer adalah data yang langsung diamati dilapangan melalui observasi dan wawancara yang mendalam. Sedangkan yang dimaksud dengan data sekunder adalah data yang sudah diolah dan dipublikasikan dari dokumentasi dan media pemberitaan resmi.Dalam penelitian ini penulis menggunakan beberapa tehnik dalam mengumpulkan data seperti Studi Literatur, Studi Lapangan yaitu obervasu, wawancara mendalam dan dokumentasi.

Dalam penelitian kualitatif, untuk objek penelitiannya menggunakan istilah situasi sosial (social situation). Situasi sosial terdiri dari tempat (place), pelaku (actors), dan aktivitas (activity). Hal ini merujuk pada apa yang disampaikan Sugiyono yang mengutip Spradley:

"Dalam penelitian kualitatif tidak menggunakan istilah populasi, tetapi Spradley dinamakan "social situation" atau situasi sosial yang terdiri atas tiga elemen yaitu: tempat (place), pelaku (actors), dan aktivitas 
(activity) yang berinteraksi secara sinergis". (Sugiyono, 2009:215).

Sanafiah Faisal (dalam Sugiyono, 2009:221) dengan mengutip pendapat Spradley mengemukakan bahwa sampel sebagai sumber data atau sebagai informan, sebaiknya yang memenuhi kriteria sebagai berikut

1. Mereka yang menguasai atau memahami sesuatu melalui proses enkulturasi, sehingga sesuatu itu bukan sekedar diketahui, tetapi juga dihayatinya

2. Mereka yang tergolong masih sedang berkecimpung atau terlibat pada kegiatan yang tengah diteliti

3. Mereka yang mempunyai waktu yang memadai untuk dimintai informasi

4. Mereka yang tidak cenderung menyampaikan informasi hasil "kemasannya" sendiri

5. Mereka yang pada mulanya tergolong "cukup asing" dengan peneliti sehingga lebih menggairahkan untuk dijadikan semacam guru atau narasumber

Situasi sosial yang menjadi penelitian ini adalah pelaksanaan PHBM melalui kegiatan pembinaan masyarakat desa hutan oleh Perum Perhutani. Informan dalam penelitian ini adalah pihak-pihak yang terlibat langsung dalam pelaksanaan kegiatan pembinaan masyarakat desa hutan. Informan dalam penelitian ini dipilih berdasarkan pertimbangan sebagai berikut:

1. Otoritas yang dimiliki informan dalam kaitannya dengan implementasi PHBM di Desa Pulosari

2. Dianggap memiliki informasi yang banyak mengenai pelaksanaan kegiatan pembinaan masyarakat di Desa Pulosari.

3. Memiliki keterkaitan, baik secara individu maupun institusi dengan pelaksanaan kegiatan pembinaan masyarakat desa hutan di desa Pulosari

Informan-informan yang dipilih berdasarkan pertimbangan tersebut adalah

1. Kepala BKPH yaitu Asisten Perhutani

2. Mandor Perum Perhutani

3. Ketua LMDH

4. Sekertaris LMDH

5. Ketua KTH

6. Ketua Koperasi Kowamah

7. Sekertaris Koperai Kowamah

\section{Anggota KTH}

Analisis data merupakan suatu proses dalam mencari dan menyusun data yang diperoleh dari hasil studi literatur, wawancara, observasi lapangan dan dokumentasi secara sistematis dengan cara mengorganisasikan data ke dalam kategori, menjabarkan ke dalam unit-unit, melakukan sintesa, menyusun ke dalam pola, memilih mana yang penting dan yang akan dipelajari, serta membuat 
kesimpulan dengan maksud agar mudah dipahami oleh diri sendiri maupun orang lain.

Tujuan analisis data ialah untuk mengungkapkan data apa yang masih perlu dicari, hipotesis apa yang perlu diuji, pertanyaan apa yg harus dijawab, metode apa yang harus digunakan untuk mendapatkan informasi baru, dan kesalahan apa yang harus segera diperbaiki (Husaini Usman, 2011:83)

Teknik analisis data digunakan untuk menjawab rumusan masalah atau menguji hipotesis yang telah dirumuskan dalam proposal. Menurut Bogdan dan Biklen dalam Husaini Usman (2011:84) analisa data ialah proses pencarian dan penyusunan data yang sistematis melalui transkrip wawancara, catatan lapangan, dan dokumentasi yang secara akumulasi menambah pemahaman peneliti terhadap yang ditemukan.

Nasution dalam Sugiyono (2009:245) menyatakan analisis telah mulai sejak merumuskan dan menjelaskan masalah, sebelum terjun ke lapangan, dan berlangsung terus sampai penulisan hasil penelitian. Dalam penelitian kualitatif, analisis data lebih difokuskan selama proses di lapangan bersamaan dengan pengumpulan data. Wujud data yang muncul dalam analisis kualitatif berwujud kata-kata bukan rangkaian angka (Miles dan Huberman, 1992).

\section{Asset Based Community Development}

Ada dua metode utama untuk mendekati pengembangan masyarakat.
Pendekatan konvensional atau tradisional adalah untuk mengidentifikasi masalah, masalah, dan kebutuhan komunitas (Phillip dan Pittman, 2009:40). Pendekatan tersebut adalah "need based". Tapi sekarang kita telah mendefinisikan pengembangan masyarakat sebagai upaya terencana untuk membangun aset yang meningkatkan kapasitas penduduk untuk meningkatkan kualitas hidup mereka. Yakni yang disebut "asset based".

Selama ini kita selalu memetakan masalah dan apa yang dibutuhkan masyarakat. Fokus kita tidak lagi pada apa yang dibutuhkan masyarakat tetapi pada potensi atau aset yang dimiliki masyarakat dan bila ada potensi yang belum maksimal maka perlu dikembangkan sehingga mereka berdaya dan dapat meningkatkan keberfungsian sosialnya.

Pengembangan masyarakat berbasis aset bertujuan untuk memberikan harapan dalam penanggulangan kemiskinan yang berkelanjutan sehingga awalnya masyarakat yang tadinya miskin dan tidak berdaya pada akhirnya keluar dari masalah tersebut dan menjadi mandiri. Hal ini sejalan dengan yang diungkapkan oleh Gary Paul Green, 2002:3) sebagai berikut

"community development has always had a diverse set of objectives; solving local problem (e.g unemployment); addressing inequalities of health and power, promoting democratic values and practice, improving the potential of 
individual residents, and building a sense of community."

Definisi di atas menekankan bahwa pengembangan masyarakat merupakan metode dalam pemecahan masalah-masalah (contoh: pengangguran) dengan adanya peningkatan potensi masyarakat diharapkan masyarakat menjadi berdaya. Selain itu, teori Asset-based community development dikeluarkan oleh Wikipedia yaitu

"methodology that seeks to uncover and utilize the strengths within communities as a means for sustainable development. The first step in the process of community development is to assess the resources of a community through a capacity inventory or through another process of talking to the residents to determine what types of skills and experience are available. The next step is to support communities, to discover what they care enough about to act. The final step is to determine how citizens can act together to achieve those goals. "

Berdasarkan penjelasan di atas bahwa pengembangan masyarakat berbasis aset merupakan metode yang bertujuan untuk memanfaatkan kekuatan yang ada didalam masyarakat sebagai sarana untuk pengembangan berkelanjutan yang didalamnya terdapat proses pengembangan untuk melihat potensi apa saja yang dimiliki masyarakat.

Langkah awal yang dilakukan dalam proses pengembangan tersebut adalah bagaimana kapasitasnya dengan melihat keterampilan dan pengalaman yang dimiliki individu tersebut. Setelah langkah awal dilakukan proses selanjutnya yaitu saling memberikan dukungan antar individu, komunitas, lalu tahap terakhir selaku warga negara kita harus melakukan proses ini bersama-sama demi kepentingan bersama dan mencapai tujuan yang diharapkan.

Yohanes Kretzmann dan John McKnight (Green dan Haines, 2002: 9) didefinisikan aset sebagai "pemberian, keterampilan dan kapasitas dari asosiasi individu dan lembaga dalam masyarakat." Pemetaan aset adalah proses pembelajaran sumber daya apa yang ada dalam komunitas. Pendekatan berbasis aset difokuskan pada kapasitas masyarakat bukan pada kelemahannya (Phillip dan Pittman, 2009:40).

Wibowo membahas tentang cara pandang baru mengenai pengembangan masyarakat yang dipopulerkan oleh Gary Paul Green (2002) yang di beri nama Asset Based Community development atau Pengembangan Masyarakat Berbasis Aset. Ini adalah pola pikir yang berasumsi bahwa hampir setiap kelompok masyarakat memiliki aset atau sumber daya yang belum tergunakan secara maksimal, alih-alih memiliki kebutuhan ataupun masalah yang harus dipenuhi/dipecahkan. Ini adalah pandangan yang berkeyakinan bahwa setiap anggota masyarakat sebenarnya memiliki kekuatan untuk mengatasi masalahnya sendiri dan 
memberdayakan potensi yang dimilikinya alih-alih memiliki kelemahan dan kekurangan yang mengakibatkan mereka selalu terbelenggu dalam berbagai kesulitan. (www.socioty-entrepreneur.com)

Asset Based Community development merupakan strategi untuk pembangunan berkelanjutan berbasis masyarakat. Gary Paul Green (2002) menyatakan ada lima konsep utama pengembangan masyarakat berbasis aset yaitu kapital manusia, kapital sosial, kapital fisik, kapital pendapatan, kapital lingkungan.

\section{Kapital Manusia (Human Capital)}

Modal manusia adalah kemampuan dan keterampilan para pekerja yang mempengaruhi produktivitas mereka. Keterampilan-keterampilan tersebut berupa keterampilan pasar tenaga kerja, keterampilan kepemimpinan, latar belakang pendidikan umum, pengembangan seni dan apresiasi, kesehatan, dan keterampilan lainnya dan pengalaman (Green dan Haines 2007: 81). Kapital Manusia merujuk pada ke dimensi individual yaitu kemampuan yang dimiliki seorang individu seperti umur, pendidikan, gender, kesehatan, dan pengalaman kerja. Hal ini sejalan dengan yang dipaparkan oleh Putnam (2000:19) sebagai berikut

"Whereas physical capital refers to physical objects and human capital refers to the properties of individuals, social capital refers to connections among individuals- social networks and the norms of reciprocity and trustworthiness that arise for them".

Dalam bukunya Gary Paul Green (2002) mendefiniskan human capital sebagai "Human capital is he abilities and skills that workers hold that affect their productivity.(Kapital manusia adalah ia kemampuan dan keterampilan para pekerja serta berpengaruh pada produktivitas mereka.. Dari penjelasan yang dikemukakan oleh Gary bahwa individu memiliki kemampuan akan keterampilan dalam bekerja dan kemampuan tersebut berpengaruh pada produktivitas mereka. Untuk memiliki kapital manusia yang baik salah satunya yaitu membangun kemampuan individu dengan meningkatkan mutu pendidikan, kesehatan, keterampilan serta memiliki pengalaman kerja. Syarat yang dibutuhkan dalam pembangunan kapasitas individu adalah memiliki tenaga kerja yang memadai, terampil, dan terlatih. Hal ini di perkuat oleh Wikipedia sebagai berikut:

"Human capital is the stock of competencies, knowledge and personality attributes embodied in the ability to perform labor so as to produce economic value. Human capital is vitally important for an organization's success (Crook 2011); human capital increases through education and experience"

Syarat yang dibutuhkan dalam pembangunan kapasitas individu adalah memiliki tenaga kerja yang memadai, terampil, dan terlatih, namun terkadang 
mengalami hambatan dalam pembangunan kapasitas individu. Organisasi berbasis masyarakat dapat mengatasi hambatan yang dialami individu tersebut bekerja sama dengan pengusaha, dan lembaga pelatihan dalam upaya pengembangan tenaga kerja. Dengan membangun jaringan tenaga kerja, mereka dapat saling memberikan informasi antara pengusaha, pekerja, dan lembaga yang terlibat dalam pasar tenaga kerja. Dengan adanya koordinasi maka beberapa kendala yang dihadapi masyarakat dalam membangun pasar tenaga kerja dapat teratasi. Membangun kapasitas individu tidak hanya dengan pelatihan saja. Hal ini sejalan dengan yang diungkapkan Harrison dan Weiss (1998) Constellation of activities from orientation to the work world, recruiting, placement, and mentoring to follow-up counseling and crisis intervention. Training is only one component of workforce development"

Dalam bukunya Gary Paul Green (2002) menjelaskan tiga fungsi dasar model pengembangan tenaga kerja sebagai berikut:This model has three basic functions: enhancing job-sp ecific skills, assisting with job-search strategies, and facilitating access to jobs by establishing relationships with employers and providing information on job opportunities. Other models may be organized differently, but they provide essestially the same services."

Dari penjelasan yang dikemukakan Gary fungsi dasar pengembangan tenaga kerja yaitu dapat meningkatkan keterampilan khusus, memudahkan masyarakat dalam mencari pekerjaan yang tepat sesuai potensi yang dimilikinya, dan memfasilitasi individu yang sedang mencari pekerjaan dengan orang yang mencari tenaga kerja sehingga memudahkan individu dalam mendapatkan informasi lapangan pekerjaan. Inti dari pengembangan tenaga kerja adalah sumber daya manusia. Dengan memiliki kapital manusia yang baik maka kualitas hidup manusia itu sendiri akan meningka

Berdasarkan teori yang dikemukakan di atas bahwa masyarakat harus meningkatkan kapasitas dirinya sendiri ke dalam bentuk keterampilan/kemampuan yang dimiliki melalui pendidikan, pelatihan yang telah diberikan sehingga mereka memiliki kapital manusia yang baik dan kualitas hidup mereka akan meningkat. Setiap individu akan termotivasi untuk meningkatkan kualitas hidupnya dengan mendapatkan penghasilan yang lebih baik maka masyarakat perlu peningkatan kapasitas dirinya agar posisi mereka di tawar dengan "mahal" di pasar tenaga kerja

\section{Kapital Sosial (Social Capital)}

Kapital lain yang juga mempunyai nilai penting yaitu kapital sosial. Kapital sosial merupakan sumberdaya yang dapat dipandang sebagai investasi. Kapital sosial merujuk pada potensi kelompok dan pola-pola hubungan antar individu dalam suatu 
kelompok yang didalamnya terdapat jaringan sosial, nilai-nilai, norma dan kepercayaan antar sesama anggota kelompok. Menurut Robert D Putnam (dalam Jousairi, 2006:14) memberikan proposisi bahwa suatu entitas masyarakat yang memiliki kebajikan sosial yang tinggi, tetapi hidup secara sosial terisolasi akan dipandang sebagai masyarakat yang memiliki tingkat kapital sosial yang rendah.

\section{Randall Collin (dalam Jousairi,} 2006:7) melakukan kajian tentang apa yang dia sebut sebagai phenomena mikro dan interaksi sosial yaitu norma dan jaringan (the norms and networks) yang sangat berpengaruh pada kehidupan organisasi sosial. Norma yang terbentuk dan berulangnya pola pergaulan keseharian akan menciptakan aturan aturan tersendiri dalam suatu masyarakat Aturan yang terbentuk tersebut kemudian akan menjadi dasar yang kuat dalam setiap proses transaksi sosial, dan akan sangat membantu menjadikan berbagai urusan sosial lebih efisien. Ketika norma ini kemudian menjadi norma asosiasi atau norma kelompok, akan sangat banyak manfaatnya dan menguntungkan kehidupan institusi sosial tersebut. Kekuatan- kekuatan sosial dalam melakukan interaksi antar kelompok akan terbentuk. Pada akhirnya mempermudah upaya mencapai kemajuan bersama.

Dalam bukunya Jousairi, Cohen dan Prusak (2001) mendefiniskan social capital sebagai berikut

"Stok dan hubungan yang aktif antar masyarakat. Setiap pola hubungan yang terjadi diikat oleb kepercayaan (trust) kesaling pengertian (mutual understanding), dan nilai-nilai bersama (shared value) yang mengikat anggota kelompok untuk membuat kemungkinan aksi bersama dapat dilakukan secara efisien dan efektif”.

Selain itu, definisi Kapital Sosial dikeluarkan oleh Bank Dunia (1999) yaitu "Sesuatu yang merujuk ke dimensi institusional, hubungan- hubungan yang tercipta, dan norma norma yang membentuk kualitas dan kuantitas hubungan sosial dalam masyarakat". Adapun Eva Cox (1995) memberikan pengertian bahwa kapital sosial sebagai: "Suatu rangkaian proses hubungan antar manusia yang ditopang oleh jaringan, norma-norma dan kepercayaan sosial yang memungkin efisien dan efektifnya koordinasi dan kerjasama untuk keuntungan dan kebaikan bersama".

Berdasarkan yang dikemukan oleh Eva Cox bahwa kepercayaan merupakan unsur yang sangat penting dalam konsep kapital sosial. Jika dalam suatu anggota kelompok berlaku jujur dan satu sama lain saling mengharapkan kejujuran maka akan timbul saling percaya diantara mereka dan memungkin terjalinnya kerjasama yang baik sehingga menghasilkan keuntungan bersama.

Menurut Hasbullah (2006), dimensi inti dari modal sosial terletak pada bagaimana kemampuan masyarakat untuk bekerjasama 
membangun suatu jaringan guna mencapai tujuan bersama. Kerjasama tersebut diwarnai oleh suatu pola inter- relasi yang imbal balik dan saling menguntungkan serta dibangun di atas kepercayaan yang ditopang oleh normanorma dan nilai-nilai sosial yang positif dan kuat.

Kekuatan tersebut akan maksimal jika didukung oleh semangat proaktif membuat jalinan hubungan di atas prinsip-prinsip sikap yang partisipatif, sikap yang saling memperhatikan, saling memberi dan menerima, saling percaya mempercayai dan diperkuat oleh nilai-nilai dan norma-norma yang mendukungnya

Terdapat 2 tipologi dari modal sosial yaitu yang berbentuk bonding/exclusive atau bridging atau inclusive. Hal tersebut diperkuat oleh dengan Green dan Haines (2002: 104) yang berpendapat bahwa bonding capital mengacu untuk membawa orang bersama-sama yang sudah saling mengenal dan tujuannya adalah untuk memperkuat hubungan yang sudah ada

Sedangkan bridging capital menyatukan orang atau kelompok yang sebelumnya tidak saling mengenal. Dan tujuan yang menjalin hubungan sosial yang baru sehingga dapat memberikan informasi baru dan mengakses jaringan sosial tambahan dan untuk mengisi "lubang struktural" dalam sistem jaringan di masyarakat (Burt dalam Green dan Haines, 2002: 104)

Dalam bukunya Jousairi (2006) terdapat 6 (enam) unsur-unsur pokok kapital sosial yaitu:

\section{a. Partisipasi Dalam Suatu Jaringan}

Kapital sosial tidak dibangun hanya oleh satu individu, melainkan akan terletak pada kecenderungan yang tumbuh dalam suatu kelompok untuk bersosialisasi. Kapital sosial akan tergantung pada kapasitas yang ada pada kelompok masyarakat untuk membangun jaringan Salah satu kunci keberhasilan membangun Kapital Sosial terletak pula pada kemampuan sekelompok orang dalam suatu asosiasi atau perkumpulan dalam melibatkan diri dalam suatu jaringan hubungan sosial.

Masyarakat selalu berhubungan sosial dengan masyarakat yang lain melalui berbagai variasi hubungan yang saling berdampingan dan dilakukan atas prinsip kesukarelaan (voluntary), kesamaan (equality), kebebasan (freedom) dan keadaban (civility). Kemampuan anggota anggota kelompok/ masyarakat untuk selalu menyatukan diri dalam suatu pola hubungan yang sinergetis akan sangat besar pengaruhnya dalam menentukan kuat tidaknya kapital sosial suatu kelompok

\section{b. Resiprocity}

Kapital sosial senantiasa diwarnai oleh kecenderungan saling tukar kebaikan antar individu dalam suatu kelompok atau antar kelompok itu sendiri. Pola pertukaran ini 
bukanlah sesuatu yang dilakukan secara resiprokal seketika seperti dalam proses jual beli, melainkan suatu kombinasi jangka pendek dan jangka panjang dalam nuansa altruism (semangat untuk membantu dan mementingkan kepentingan orang lain). Dalam konsep Islam, semangat semacam ini disebut sebagai keikhlasan. Semangat untuk membantu bagi keuntungan orang lain. Imbalannya tidak diharapkan seketika dan tanpa batas waktu tertentu. Pada masyarakat, dan pada kelompok- kelompok sosial yang terbentuk, yang di dalamnya memiliki bobot resiprositas kuat akan melahirkan suatu masyarakat yang memiliki tingkat keuntungan lain, masyarakat tersebut akan lebih mudah membangun diri, kelompok dan lingkungan sosial dan fisik mereka secara mengagumkan.

\section{c. Rasa Percaya}

Trust atau rasa percaya (mempercayai) adalah suatu bentuk keinginan untuk mengambil resiko dalam hubungan-hubungan sosialnya yang didasari oleh perasaan yakin bahwa yang lain akan melakukan sesuatu seperti yang diharapkan dan akan senantiasa bertindak dalam suatu pola tindakan yang saling mendukung, paling tidak. yang lain tidak akan bertindak merugikan diri dan kelompoknya (Robert D Putnam, 1993, 1995, dan 2002). Dalam pandangan Fukuyama (1995, 2002), trust adalah sikap saling mempercayai di masyarakat yang memungkinkan masyarakat tersebut saling bersatu dengan yang lain dan memberikan kontribusi pada peningkatan Kapital Sosial.

\section{d. Norma Sosial}

Norma-norma sosial akan sangat berperan dalam mengontrol bentuk-bentuk perilaku yang tumbuh dalam masyarakat. Pengertian norma itu sendiri adalah sekumpulan aturan yang diharapkan dipatuhi dan diikuti oleh anggota masyarakat pada suatu entitas sosial tertentu. Norma-norma ini biasanya terinstusionalisasi dan mengandung sangsi sosial yang dapat mencegah individu berbuat sesuatu yang menyimpang dan kebiasaan yang berlaku di masyarakatnya. Aturan-aturan kolektif tersebut biasanya tidak tertulis tapi dipahami oleh setiap anggota rnasyarakatnya dan menentukan pola tingkah laku yang diharapkan dalam konteks hubungan social

\section{e. Nilai-nilai}

Nilai adalah sesuatu ide yang telah turun temurun dianggap benar dan penting oleh anggota kelompok masyarakat, misalnya nilai harmoni, prestasi, kerja keras, kompetisi dan lainnya serta nilai-nilai tersebut merupakan nilai-nilai yang umum dikenal dalam kehidupan masyarakat. Nilai harmoni misalnya yang banyak pihak dianggap pemicu keindahan, kerukunan hubungan sosial yang tercipta, tetapi di sisi lain dipercaya pula untuk senantiasa menghasilkan kenyataan 
yang menghalangi kompetisi dan produktivitas.

Pada kelompok masyarakat yang mengutamakan nilai-nilai harmoni biasanya senantiasa ditandai oleh suatu suasana yang rukun, indah, namun dalam hal hal diskusi pemecahan masalah, tidak produktif. Kapital sosial yang kuat juga sangat ditentukan oleh konfigurasi nilai yang tercipta pada suatu kelompok masyarakat. Jika kelompok tersebut memiliki bobot tinggi pda kompetisi, pencapaian, keterusterangan dan kejujuran maka kelopok masyarakar tersebut cenderung lebih berkembang dibandingkan pada kelompok masyarakat yang menghindari keterusterangan, kompetisim dan pencapaian. Pada setiap kebudayaan biasanya terdapat nilai-nilai tertentu yang mendominasi ide berkembang. Dominasi ide tertentu dalam masyarakat akan membentuk dan mempengaruhi aturan-aturan bertindak masyarakatnya dan aturan-aturan bertingkah laku.

\section{f. Tindakan Proaktif}

Salah satu unsur penting kapital sosial adalah keinginan yang kuat dan anggota kelompok untuk tidak saja berpartisipasi tetapi senantiasa mencari jalan bagi keterlibatan mereka dalam suatu kegiatan masyarakat. Ide dasar dan premise ini, bahwa seseorang atau kelompok senantiasa kreatif dan aktif. Mereka melibatkan diri dan mencari kesempatan kesempatan yang dapat memperkaya, tidak saja dan sisi material tapi juga kekayaan hubungan hubungan sosial, dan menguntungkan kelompok, tanpa merugikan orang lain, secara bersama-sama. Mereka cenderung tidak menyukai bantuan bantuan yang sifatnya dilayani, melainkan lebih memberi pilihan untuk lebih banyak melayani secara proaktif.

\section{Kapital Fisik}

Kapital fisik merupakan salah satu modal dasar yang terdapat dalam setiap masyarakat. Green dan Haines (2002:113) melihat dua kelompok utama dari modal fisik adalah bangunan dan infrastruktur. Bangunan yang dimaksud berupa rumah, pertokoan, perkantoran, gedung perniagaan, dan sebagainya. Sebagian infrastruktur dapat berupa jalan raya, jembatan, jalan kereta api, sarana pembangunan limbah, sarana air bersih, dan sebagainya.

Dalam konteks pengembangan masyarakat, kapital fisik mengacu pada bangunan seperti rumah, toko retail, pabrik dan infrastruktur seperti jalan, air, saluran pembuangan. Masyarakat berpandangan ketika mereka membangun rumah (kapital fisik), maka rumah tersebut dianggap sebagai sebuah investasi dan diharapkan akan memperoleh keuntungan dari investasi tersebut. Keuntungan yang diperoleh bisa berupa penjualan, warisan, ataupun di kontrakan kepada orang lain. Kapital fisik bersifat bertahan pada periode yang lama dan 
tidak bergerak atau berpindah tempat. Dengan demikian, kualitas kapital fisik lokal adalah penting dalam konteks pengembangan masyarakat.

Dalam ilmu ekonomi, kapital fisik mengacu pada aset yang sudah diproduksi yang diterapkan dalam produksi, seperti mesin, bangunan, atau kendaraan. Dalam teori ekonomi, kapital fisik adalah salah satu dari tiga faktor utama produksi, juga dikenal sebagai masukan dalam fungsi produksi. Yang lainnya adalah sumber daya alam (termasuk tanah), dan tenaga kerja. Hal ini sejalan dengan yang dipaparkan oleh Wikipedia sebagai berikut

"In economics, physical capital or just 'capital' refers to any alreadymanufactured asset that is applied in production, such as machinery, buildings, or vehicles. In economic theory, physical capital is one of the three primary factors of production, also known as inputs in the production function. The others are natural resources (including land), and labor - the stock of competences embodied in the labor force. "Physical" is used to distinguish physical capital from human capital (a result of investment in the human agent)) and financial capital. "Physical capital" may also refer to fixed capital, any kind of real or physical asset that is not used up in the production of a product, as distinguished from circulating capital'.

Perumahan merupakan hal yang penting bagi setiap anggota masyarakat karena selain untuk tempat tinggal, rumah pun dijadikan ruang pribadi untuk keluarga dan teman. Kondisi lingkungan yang baik, penampilan fisik bagus mencirikan perumahan yang berkualitas. Perumahan yang berkualitas dapat memberikan setiap anggota masyarakat dengan citra positif, hal tersebut menunjukkan kepedulian kita terhadap tempat tinggal kita dan lingkungan. Ini sejalan dengan yang dipaparkan oleh (Clay,1992. P.23) sebagai berikut

"Housing is major component in the bundle of goods that define social and economic well-being for American families. It is an indicator of the social status of families and individuals, it is the largest invesment most people make and makes up the majority of most families net worth. It is also the largest part of most households budgets, generally, around 20\%, but often a third or more for families of limited means"

Berdasarkan definisi Clay di atas bahwa Perumahan adalah komponen utama yang mendefinisikan sosial dan kesejahteraan ekonomi bagi keluarga Amerika. Ini merupakan indikator status sosial keluarga dan individu, itu adalah investasi terbesar kebanyakan orang membuat dan menjadi mayoritas dari keluarga yang paling layak bersih. Upaya untuk memproduksi dan merenovasi perumahan dengan harga yang terjangkau adalah tempat berbasis strategi dalam pengembangan masyarakat. Untuk memahami perumahan di komunitas apapun, kita perlu memahami pasar perumahan lokal

Pasar perumahan lokal adalah sistem yang rumit dan kompleks. Sebuah pasar 
perumahan terjadi di suatu daerah dan dibentuk oleh interaksi permintaan dan kekuatan. Kekuatan ini meliputi jumlah dan karakteristik rumah tangga dan daya beli mereka, komposisi dan kondisi perumahan yang ada, jenis jabatan, tingkat pembentukan rumah tangga, kemampuan untuk membayar perumahan yang layak, tingkat kualitas kemiskinan, dan tingkat pemerintah subsidi dan lingkungan peraturan (Huttman, 1988, pp6-7).

\section{Kapital Keuangan}

Selain kapital fisik, modal lain yang cukup diperhitungkan dalam menentukan kesejahteraan suatu komunitas adalah kapitas keuangan. Kapital keuangan dapat merujuk pada uang yang digunakan oleh pengusaha dan perusahaan untuk membeli apa yang mereka butuhkan untuk membuat produk atau menyediakan layanan mereka atau bahwa sektor ekonomi berdasarkan operasinya, yaitu perbankan investasi, dll. Kebanyakan pasar kredit merespon kebutuhan masyarakat miskin karena pada umumnya mereka kurang memiliki akses ke kapital keuangan. Kebanyakan dari mereka mengembangkan lembaga kredit alternatif untuk memenuhi kebutuhan kredit mereka.

Dalam bukunya Gary Paul Green (2002) dibahas mengenai keterkaitan antara asset yang satu dengan yang lain, sebagai berikut

"Like the other assets discusses in this book, there is a strong relationship between financial capital and the other forms of capital. much of the focus on physical capital has been on developing financial mechanisms to provide affordable housing.human capital strategies focusing on self employment often emphasize the importance of debt and equity capital to help new bussinesses start and grow. strategies for building environmental capital also rely heavily on developing pools of capital to purchase land. finnaly we will discuss how social capital is often intimately tied to access to financial capital in many communities. in many ways financial capital is the lifeblood of communities".

Berdasarkan uaraian di atas bahwa terdapat hubungan kuat antara kapital keuangan dan bentuk lainnya seperti fisik, lingkungan, sosial dan manusia. Fokus kapital fisik pada pengembangan mekanisme keuangan untuk menyediakan strategi perumahan dengan kapital yang terjangkau. Kapital manusia berfokus pada wirausaha dengan menekankan pentingnya utang dan kapital untuk membantu usaha bisnis yang baru. strategi untuk membangun kapital lingkungan juga sangat bergantung pada pengembangan kapital keuangan untuk membeli tanah. Terakhir, kapital sosial sangat terkait dengan akses ke kapital keuangan di banyak komunitas. Karena di dalam banyak kapital keuangan adalah darah kehidupan masyarakat.

\section{Kapital Lingkungan}




\section{Kapital lingkungan mencakup} beberapa aspek dasar masyarakat sumber daya alam yaitu udara, air, tanah, flora dan fauna. Kapital lingkungan sangat kompleks, baik dalam bagaimana cara masyarakat bekerja dalam lingkungannya dan bagaimana untuk menjaga, melestarikan, dan menggunakan kapital yang tepat dan dengan benar. Masyarakat harus peduli pada lingkungan sekitarnya serta memperhatikan tentang fungsi ekologis sumber daya alam seperti pengendalian banjir, DAS, dan asimilasi limbah. Sumber daya alam pun memiliki nilai penggunaan langsung, output utama yang dipasarkan misalnya kayu, tanaman, energi terbarukan dan manfaat lainnya seperti rekreasi. Akhirnya sumber daya alam dapat memiliki nilai untuk generasi masa depan atau sumber daya alam yang sedang dilestarikan, karena sumber daya alam dapat menghasilkan berbagai nilai serta penggunaan terbaik dari sumber daya untuk kelangsungan hidup jangka panjang dari masyarakat.

\section{HASIL}

Penelitian ini merupakan penelitian yang bersifat kualitatif, dimana peneliti telah mengambil 8 (delapan) orang menjadi informan. Informan tersebut memiliki pengetahuan dan pengalaman pada pelaksanaan Pengelolaan Hutan Bersama Masyarakat melalui kegiatan pembinaan masyarakat. Pembahasan dimulai dari deskripsi informan, deskripsi pelaksanaan kegiatan pembinaan masyarakat dan analisa pemanfaatan Asset Based Community Development dalam kegiatan pembinaan masyarakat

Sebelum menguraikan pembahasan mengenai PHBM melalui kegiatan pembinaan masyarakat desa hutan, dalam hal ini masyarakattersebut berdomisili di desa Pulosari Kecamatan Pangalengan Kabupaten Bandung Selatan, terlebih dahulu akan dikemukakan mengenai karakteristik informan. Adapun ringkasan mengenai karakteristik informan disajikan pada tabel sebagai berikut

\begin{tabular}{|c|c|c|c|c|c|c|}
\hline \multirow{2}{*}{ No } & \multirow{2}{*}{ Informan } & \multicolumn{5}{|c|}{ Keterangan } \\
\cline { 3 - 7 } & Nama & $\begin{array}{c}\text { Umur } \\
\text { (tahun })\end{array}$ & Jabatan & Pend & Pekerjaan \\
\hline 1 & Informan 1 & Wawan & 47 & $\begin{array}{c}\text { Asisten, Perhutani } \\
\text { (KBKPH) }\end{array}$ & SMA & $\begin{array}{c}\text { Pegawai Perum } \\
\text { Perhutani }\end{array}$ \\
\hline 2 & Informan 2 & Enjang & 62 & Ketua LMDH & SMA & Petani kopi \\
\hline 3 & Informan 3 & Jamhur & 70 & Sekertaris LMDH & S1 & Petani kopi \\
\hline 4 & Informan 4 & Amas & 67 & Ketua KTH & SMP & Petani kopi \\
\hline
\end{tabular}




\begin{tabular}{|l|l|c|c|c|c|c|}
\hline 5 & Informan 5 & Dodo & 59 & Ketua KTH & SD & Petani Kopi \\
\hline 6 & Informan 6 & Rukiman & 50 & Mandor Perhutani & SPMP & $\begin{array}{c}\text { Pegawai Perum } \\
\text { Perhutani, }\end{array}$ \\
\hline 7 & Informan 7 & $\begin{array}{r}\text { Rusnand } \\
\text { Ar }\end{array}$ & 58 & $\begin{array}{c}\text { Ketua Koperasi, } \\
\text { Bendahara LMDH }\end{array}$ & SMU & Petani Kopi \\
\hline 8 & Informan 8 & $\begin{array}{c}\text { Undang } \\
\text { Nasihin }\end{array}$ & 47 & Anggota Kelompok & S2 & Petani kopi \\
\hline
\end{tabular}

Sumber: Penelitian

Adapun ringkasan pelaksanaan

kegiatan pembinaan masayarakat desa hutan sebagai berikut

\section{Tahap Sosialisasi}

Petugas Perhutani membahas mengenai Pengelolaan Sumberdaya hutan dan memberikan pembinaankepada MDH tentang aspek teknis seperti teknik budidaya, konsevasi hutan dan pengamanan hutan

Para pihak yang terlibat yaitu Petugas Perum Perhutani, Tim Pendamping (LSM), MDH, Aparat pemerintah Desa, BPD, investor dan kepolisian Sosialisasi biasanya dilakukan setiap satu bulan sekali atau dua bulan sekali dalam bentuk pertemuan formal maupun informal.

\section{Tahap Dialog}

Diskusi antara para pihak untuk mewujudkan persamaan persepsi tentang pengelolaan sumber daya hutan Perum Perhutani menyampaikan cara peningkatan produksi kayu, menjaga hutan, pembentukan kelembagaan dan peraturan kebijakan Perum Perhutani Para pihak yang terlibat yaitu
Petugas Perum Perhutani, Tim Pendamping (LSM), MDH, Aparat pemerintah Desa, $\mathrm{BPD}$, investor dan kepolisian

\section{Tahap Negosiasi:}

Tawar menawar untuk mencapai kesepakatan hak-hak dan kewajiban para pihak serta dalam pembentukan kelembagaannya.

Tempat pelaksanaan negosiasi biasa dilakukan di Gubug kerja, atau di rumah warga yang dihadiri para pihak terkait.

\section{Tahap Aspek Legal :}

Penandatangan perjanjian kerjasama antar para pihak dan disahkan oleh notaris

\section{Tahap Pelaksanaan :}

Melaksanakan hak-hak dan kewajiban para pihak sesuai dengan PKS

\section{Tahap Monitoring dan Evaluasi}

proses pemantauan dan pengawasan terhadap seluruh aktifitas berupa pelaksaan hak-hak dan kewajiban kedua belah pihak sesuai isi surat perjanjian kerjasama agar 
diketahui sejauh mana hak-hak dan kewajiban para pihak tersebut telah dan atau belum dilaksanakan

\section{Tahap Rencana Tindak Lanjut:}

Perencanaan kegiatan tindak lanjut yang belum terlaksana sesuai hasil monitoring dan evaluasi

Perhutani telah melakukan upaya pengembangan masyarakat dalam bentuk program PHBM berupa pelaksanaan kegiatan pembinaan masyarakat. Adapun pemanfaatan aset/potensi/sumber dapat dijelaskan sebagai berikut:

\section{Kapital Manusia}

Kekuatan masyarakat yang menjadi titik tolak berkembangnya suatu negara yaitu terkait dengan unsur manusia yang menjadi modal dasar pembangunan mereka. Tanpa adanya unsur manusia yang memiliki kemampuan yang memadai, maka aset lainnya kurang dapat dimanfaatkan secara optimal. Salah satu unsur yang penting dalam menyiapkan modal manusia adalah unsur pendidikan. Sebagian besar tingkat pendidikan masyarakat di Desa Pulosari masih

relatif rendah.

Ketertinggalan modal manusia tidak hanya dilihat dari aspek pendidikan saja, tapi dilihat juga dari aspek keterampilan dan keahlian yang dimiliki masyarakat. Mata pencaharian masyarakat desa hutan awalnya petani sayur mayur, ada yang peternak, dan jasa ojeg. Sebelumnya keterampilan yang dimiliki hanya bertani, beternak dan kebanyakan pengangguran, tidak memiliki keterampilan apa-apa. Berdasarkan hasil penelitian, PHBM melalui kegiatan pembinaan masyarakat memberi manfaat dalam penyediaan lapangan pekerjaan dan mengurangi pengangguran. Setiap hektar tanaman kopi memerlukan antara 2- 5 tenaga kerja untuk melakukan pekerjaan pemetikan kopi, pengolahan hasil dan lain-lain. Hal ini diperkuat oleh pernyataan informan sebagai berikut:

"Setiap hektar tanaman kopi memerlukan minimal 2 orang tenaga kerja, 5 orang tenaga petik di musim panen sedangkan untuk pengolahan hasilnya, setiap 10 hektar tanaman kopi memerlukan tenaga kerja pengolahan gabah diperlukan 3 orang tenaga kerja dan pengolahan beras diperlukan minimal 20 orang tenaga kerja. Dengan demikian untuk 10 hektar tanaman kopi akan menyerap tenaga kerjasekitar 30 orang dan apabila setiap tenaga kerja mempunyai tanggungan keluarga maka tanaman kopi seluas 30 hektar akan memberi makan 300 orang" (informan 1)

Namum demikian di desa Pulosari juga memiliki beberapa tenaga ahli dari warga setempat yaitu lulusan sarjana pertanian dan lulusan administrasi negara. Mereka ahli di bidangnya masing-masing untuk memajukan kopi di Kubang Sari Secara ringkas, pembangunan manusia disektor pendidikan dan keterampilan memberikan gambaran umum tentang aset manusia yang dimiliki masyarakat desa hutan Kubang Sari. Aset-aset 
ini lah yang menjadi aset untuk tenaga kerja yang diandalkan untuk meningkatkan taraf kesejahteraan masyarakat.

\section{Kapital Sosial}

Aset lain yang mempunyai peranan penting adalah modal sosial dalam suatu masyarakat yang menjadi penghubung antara kelompok masyarakat satu dengan yang lainnya. Modal sosial yang dimaksud adalah nilai-nilai dan norma yang berlaku (aturan yang mengikat warga masyarakat didalamnya), mengatur pola perilaku, adanya unsur kepercayaan, adanya jaringan. Salah satunya bentuk partisipasi masyarakat yaitu gotong royong dan dalam PHBM masyarakat terlibat secara aktif.

Bentuk partisipasi yang dilakukan anggota biasanya berupa memperbaiki jalan hutan, membersihkan lingkungan sekitar hutan, menjaga hutan bersama-sama agar tidak ada penebangan, perlunya memupuk dan menumbuhkan rasa kesadaran masyarakat akan cinta terhadap lingkungannya dan memelihara kelestarian hutan. Dengan adanya kegiatan ini secara langsung masyarakat terlibat aktif dalam menjaga dan merawat hutan, tidak hanya menjaga tanaman kopi saja. Disini menunjukan manfaat kapital sosial akan mampu mendorong pelaksanaan kegiatan PHBM. Hal ini diperkuat oleh pernyataan informan sebagai berikut

"sebelum adanya PHBM masyarakat aktif dalam gotong royong seperti menjenguk orang yang sakit, meninggal, ikut membantu pembangungan mesjid, penyaluran air. Setelah ada PHBM pun masyarakat tetap aktif gotong royong, namun berbeda dari kegiatannya saja, seperti mengelola hutan, menjaga hutan , membuat jalan di kawasan hutan." (informan 2)

Pembinaan biasanya dilakukan oleh Perum Perhutani, namun pelatihan dan penyuluhan banyak dilakukan oleh dinas Perkebunan. Anggota kelompok ikut aktif dalam kegiatan tersebut. Disamping itu anggota kelompok tani pun ikut aktif menjadi anggota LMDH. Hal ini diperkuat oleh pernyataan informan sebagai berikut:

"anggota kelompok ikut terlibat dalam kegiatan yang telah disepakati oleh para pihak dalam hal kelembagaan, pembinaan, pendidikan dan pelatihan.” (informan 3)

Para petani desa hutan Kubang Sari merupakan kelompok orang yang memiliki minal-minat yang sama sebagai anggota kelompok. Kelompok ini memiliki batas geografis disesuaikan dengan lahan kerja mereka. Lahan kerja mereka disesuaikan berdasarkan masuk ke kelompok mana, petak berapa dan berapa hektar yang di garap oleh mereka. Di Kubang Sari terdapat 13 Kelompok Tani hutan. Luas lahan garapan mereka 625 ha. Partisipasi para anggota kelompok tani sangat diperlukan dalam kegiatan tersebut. hal ini ditandai dengan kehadiran mereka, tidak hanya pada tahap pelaksaanaannya saja, namun ikut hadir dalam pertemuan-pertemuan yang dilakukan baik oleh Perhutani, Lembaga Masyarakat 
Desa Hutan, dan ketua Kelompok Tani hutan.

Partisipasi dalam kegiatan ini anggota berperan lebih banyak mendengar dan memberikan kepercayaan kepada pada pengurus Lembaga dan Ketua Kelompok. Oleh karena itu mereka kurang memahami secara mendalam mengenai stategi yang seharusnya dilakukan dalam mencapai tujuan tersebut. Komunikasi yang dilakukan hanya satu arah saja atau tidak komunikatif. Ketua kelompok mempunyai peranan penting dalan kegiatan pembinaan masyarakat sekaligus mengkoordinir juga menjembatani antara para pihak yaitu perum perhutani, lembaga dan anggota. Salah satunya yaitu mendengarkan aspirasi masyarakat lalu disampaikan kepada pihak perhutani dan lembaga.

Hal ini di perkuat oleh pernyataan informan sebagai berikut:

"saya sebagai ketua kelompok biasanya mengkoordinir anggota untuk mengikuti rapat, memang ada beberapa rapat yang hanya dihadiri oleh pengurus LMDH, ketua KTH dan beberapa anggota saja. Biasanya beberapa anggota lain yang tidak hadir saya sampaikan hasil rapat atau informasi terbaru melalui pertemuanpertemuan informal" (informan 3)

Masyarakat terlibat aktif dalam pelaksanaan PHBM, terlibat dalam keanggotan dan kelembagaan yang telah dibentuk. Ketua mempunyai peranan dalam melakukan pembinaan dan mengecek bila ada anggotanya yang belum memahami aspek teknis di lapangan seperti cara penanaman, pembibitan, pemeliharaan, pemanenan dan pemasara. Hal dimaksud sebagai tugas ketua kelompok tani hutan. Ini pun salah satu cara membangun komunikasi dan bersosialisasi antar anggota, selain meningkatkan kapasitas lembaga itu sendiri, mampu mengkoordinir dan bekerja sama serta melibatkan anggota dalam hal apapun. Agar membangun kepercayaan terhadap ketua, sesama anggota, satu sama lain harus saling transparan atau terbuka. Tidak boleh mencurangi sesama anggota, saling menghargai, menghormati pendapat masing-masing anggota, merupakan nilai-nilai yang ada di masyarakat desa hutan.

\section{Kapital fisik}

Modal fisik merupakan salah satu modal dasar yang terdapat dalam setiap masyarakat. Green dan Haines melihat dua kelompok utama dari modal fisik adalah bangunan dan infrastruktur. Bangunan yang dimaksud dapat berupa rumah, pertokoan, gedung, perniagaan dan lain-lain. Adapun bangunan yang dimiliki masyarakat yaitu, sekertariat LMDH, koperasi tani hutan (koptanhut) yang diberi nama Kowamah, pabrik pengolahan kopi yang didalamnya terdapat mesin-mesin pengolahan dari mulai pengolahan gabah sampai siap seduh. Hal ini diperkuat oleh pernyataan informan sebagai berikut:

"LMDH memiliki sekertariat lembaga, gubug-gubung kerja, koperasi, dan mesin-mesin pengolahan kopi" (informan 3)

Sedangkan infratruktur dapat berupa 
jalan raya, jembatan , jalan kereta api, sarana pembuangan limbah, air bersih dan lainlain. Infrastruktur yang dimiliki berupa Luas Hutan Pangkuan Desa 625 ha, luas tanaman kopi arabika 425 ha, memiliki air bersih, dan berkat hutan kembali subur, air bersih bisa dimanfaatkan oleh masyarakat. Masyarakat ikut merasakan langsung efek dari menjaga kelestarian hutan. Selain itu memiliki jalan, penerangan umum, hal ini diperkuat oleh informan sebagai berikut:

"Aset yang dimiliki LMDH berupa sekertariat lembaga dan pabrik yaitu luas hutan pangkuan desa 625 ha, tanaman kopi arabika 425 ha, sisanya menanam rumput gajah untuk keperluan ternak mereka, di Kubang Sari ada air bersih dan berkat bantuan bank dunia membuat saliran air sehingga masyarakat bisa merasakan langsung air bersih" (informan 2)

Lembaga masyarakat desa hutan atau biasa disingkat LMDH memiliki mesin pengolahan, kantor sekertariat, Pabrik pengolahan.sarana prasarana masih belum memadai faktor penunjang lain seperti bibit, alat kerjam pupuk masih kurang. Dan sangat mempengaruhi hasil panen. Disamping air, ada banyak potensi yang terdapat di Kubang Sari. Salah-satu yang paling menonjol adalah potensi wisata. Namun agar pengembangan berjalan maksimal dibutuhkan dukungan dari berbagai pihak, terutama pemertintah. Sumber daya hutan yang kaya akan potensi dan bisa dikembangkan sebagai wisata pendidikan budidaya kopi dan PHBM, wana agro wisata dengan basis budidaya kopi, sumberdaya manusia berwawasan perkopian ke depan yang memiliki kemampuan mempersatukan petani kopi di Jawa Barat, adanya kepercayaan Perum Perhutani pada LMDH Kubang Sari sebagai leader pelaksaan PHBM dan budidaya kopi di $\mathrm{n}$ wilayah KPH Bandung Selatan.

\section{Kapital Keuangan}

Selain modal Fisik, modal lain yang perlu diperhitungkan dan menentukan kesejahteraan masyarakat desa hutan adalah modal keuangan. Di kubang sari sumber keuangan berasal dari masyarakat (swadaya). Anggota masih terkendala dengan modal, dalam pengadaan bibit dan pupuk diperlukan modal yang besar jika ingin hasil panennya lebih baik. Awalnya Perhutani membentuk koperasi agar masyarakat bisa melakukan simpan pinjam, mendapat modal dari operasi. Namun pada kenyataannya koperasi belum mampu menyediakan modal untuk para anggotanya. Hal ini diperkuat oleh informan sebagai berikut

"koperasi belum berjalan secara optimal, koperasi hanya menyalurkan hasil panen, peminjaman bibit hanya beberapa saja, simpan pinjam pun terbatas, dan sekarang simpan pinjam sudah tidak aktif lagi” (informan 4)

"pernah terjadi konflik mengenai koperasi dan masyarakat sudah tidak percaya lagi dengan koperasi, anggota banyak yang menjual kopi tidak ke koperasi dan lembaga yang seharusnya diserahkan ke kelompok dan bagi hasi dengan perhutani. karena banyaknya pendatangpendatang yang membeli kopi dengan 
harga lebih tinggi masyarakat menjual kesana." (informan 2)

Ada beberapa organisasi yang terlibat dalam pengelolaan hutan bersama masyarakat dalam hal budidaya kopi yaitu APEKI (asosiasi Petani Kopi Indonesia) APEKI tugasnya yaitu mengajukan dana aspirasi ke anggota dewan, ke dinas-dinas terkait, seperti dinas perkebunan, pertanian dan menentukan pasar untuk hasil panen kopi, AEKI (asosiasi ekspor kopi Indonesia), namun kopi di Kubang Sari belum ada hak paten, jadi bila dibeli oleh Surabaya (PT Indokom), Kopi surabaya, sehingga diperlukan pengakuan hak paten bagi kopi Kubang Sariagar nilai jual lebih tinggi. Dengan adanya sertifikasi hak paten akan menambah nilai jual kopi Kubang Sari dan masyarakat menjadi sejahtera.

\section{Kapital Lingkungan}

Modal lain yang penting adalah adanya modal lingkungan yang dapat diakses dan dimanfaatkan oleh masyarakat. Modal lingkungan dapat berupa potensi yang belum diolah dan memiliki nilai ekonomi yang tinggi, dan mempunyai nilai tinggi dalam upaya pelestarian seperti tidak terjadinya erosi, longsor. Sebelum adanya PHBM hutan gundul dan masyarakat menanam sayurmayursehingga tidak tersedia air bersih. Setelah adanya sosialisasi dan kesepakatan untuk menanam tanaman keras yaitu kopi dan kayu. Pada sosialisasi pun masyarakat diberikan 3 pilihan yaitu alih lokasi, alih profesi atau alih komoditi. Hutan menjadi hijau kembali dan masyarakat bisa menanam kopi di hutan. Dari aspek lingkungan kopi bisa tumbuh dibawah naungan tanaman hutan. Sehingga masyarakat menjaga hutan dengan baik.

Dalam kaitannnya dengan konsep pekerjaan sosial, Perum Perhutani dapat berfungsi sebagai sistem sumber, Soetarso (1995) mengungkapkan bahwa

"Inti sasaran fokus praktek pekerjaan sosial adalah interaksi diantara orang dengan sistem-sistem sumber di lingkungan sosial mereka. Orang yang mengantungkan dirinya pada sistem ini untuk memperoleh sumber-sumber material, emosional, dan pelayananpelayanan serta kesempatankesempatan yang mereka butuhkan untuk mewujudkan aspirasi mereka dan juga untuk membantu mereka dalam pelaksanaan tugas-tugas kehidupan mereka”. (1995:2)

Dalam kaitannya dengan sistem sumber, ada beberapa lembaga formal dalam pelaksanaan PHBM yaitu Lembaga Masyarakat Desa Hutan, Lembaga Ekonomi, Lembaga Swadaya Masyarakat dan Koperasi. Lembaga-lemabaga tersebut termasuk kategori sistem sumber formal. Pincus dan Minahan (1973) mendefinisikan sistem sumber formal sebagai berikut:

"sistem sumber formal adalah sumber yang dapat memberikan bantuan atau pelayanan langsung terutana kepada anggotanya. Selain kepada para anggotanya, sumber ini juga dapat memberi manfaat kepada masyarakat yang membutuhkannya".

Dengan demikian Perum Pehutani 
termasuk dalam kategori sistem sumber formal, karena LMDH, LSM dan koperasi merupakan lembaga-lembaga formal yang memberikan bantuan dan pelayanan langsung kepada para petani yang termasuk anggotanya. Bantuan yang diberikan oleh sistem sumber tersebut berupa kegiatankegiatan ataupun program yang dilaksanakan untuk anggotanya yaitu para petani baik langsung maupun tidak langsung. Hal ini sesuai dengan visi Perum Perhutani yaitu menjadi pengelola hutan lestari untuk sebesarbesarnya kemakmuran rakyat. Selain itu masyarakat desa hutan merasakan dampak positif dengan adanya pengelolaan hutan bersama masyarakat.

Pengembangan masyarakat sebagai upaya terencana untuk membangun aset/potensi/sumber dalam rangka peningkatan kapasitas masyarakat untuk mewujudkan kualitas hidup masyarakat. Yakni disebut “Asset Based ”. Biasanya bentuk pengembangan masyarakat yang dilakukan berupa pemetaan masalah dari apa yang dibutuhkan masyarakat. Namun sekarang dilihat dari potensi/aset/sumber yang dimiliki masyarakat yang dapat dikembangkan sehingga masyarakat berdaya dan dapat meningkatkan kualitas hidup mereka.

Perum Perhutani telah melakukan upaya pengembangan masyarakat dalam bentuk program PHBM berupa pelaksanaan kegiatan pembinaan masyarakat. Adapun pemanfaatan aset/potensi/sumber dalam tahapan pelaksanaan kegiatan pembinaan masyarakat desa hutan dapat dijelaskan sebagai berikut:

\section{Sosialisasi}

Sosialisasi merupakan tahap awal dalam kegiatan pembinaan masyarakat desa hutan yaituPetugas Perum Perhutani dan Tenaga Pendamping Masyarakat (TPM) yang berasal dari Lembaga Swadaya Masyarakat (LSM) melakukan arahan dan bimbingan mengenai program PHBM. Adapun materi sosialisasi tidak hanya mengenalkan tentang PHBM dan diperbolehkannya masyarakat mengelola lahan Perum Perhutani, namun juga diberikan pemahaman secara luas manfaat sumberdaya hutan bagi kehidupan masyarakat desa hutan dan teknis-teknis penanaman, pemeliharaan dan pemanenan tanaman hutan maupun tanaman semusim serta pemasarannya. Adapun pemanfaatan aset-aset dalam tahapan sosialisasi ini yaitu:

\section{Kapital Manusia}

Pemanfaatan kapital manusia dimanfaatkan dengan baik oleh Perum Perhutani hal ini ditandai dengan tenaga ahli lokal (local expert) sehingga anggota memmiliki keahlian dan keterampilan baru

\section{Kapital Sosial}

Pemanfaatan kapital sosial dijalan kan dengan baik hal ini ditandai dengan masyarakat ikut terlibat aktif dalam pengelolaan hutan bersama 
masyarakat, ikut dalam kelembagaan dan menjadi anggota, berpartisipasi aktif dalam pertemuan-pertemuan formal maupun informal yang dilakukan Perhutani, maupun pihak Lembaga namun ada beberapa yang belum terlaksana secara optimal yaitu partisipasi anggota kelompok tani masing kurang, hal ini diindikasikan ketidakhadiran beberapa anggota kelompok tani pada tahap Sosialisasi. Anggota petani memberikan kepercayaan kepada Lembaga Masyarakat Desa Hutan dan Ketua Kelompok Tani Hutan sehungga mereka tidak memahami secara kompherensif mengenai pengeloaan hutan

\section{Kapital Fisik}

Pemanfaatan kapital fisik dimanfaatkan dengan baik hal ini ditandai dengan adanya masyarakat merasakan manfaat air bersih dari hutan. Lembaga masyarakat desa hutan memiliki mesin pengolahan, kantor sekertariat, Pabrik pengolahan.sarana prasarana masih belum memadai faktor penunjang lain seperti bibit, alat kerjam pupuk masih kurang.dan sangat mempengaruhi hasil panen

\section{Kapital keuangan}

Pemanfataan kapital keuangan yaitu sampai saat ini dana untuk kegiatan mengelola lahan garapan milik Perhutani berasal dari masyarakat (swadaya). Ada koperasi namanya KOWAMAH, koperasi warga masyarakat hutan, namum belum berjalan optimal terbentur oleh dana.

\section{Kapital Lingkungan}

Dalam tahapan ini pemanfaatan kapital lingkungan tidak diperlukan karena kapital lingkungan berupa sumber daya hutan, air bersih, dan kondisi cuaca dan iklim diperlukan pada tahapan pelaksanaan kerjasama.

\section{Dialog}

- Tahap Dialog merupakan komunikasi dua arah antara Petugas Perum Perhutani dan para anggota KTH, agar terwujud kesepahaman bersama terhadap pengelolaan sumber daya hutan. Dalam tahap dialog ini petugas Perhutani menyampikan kegiatankegiatan yang telah direncanakan oleh Perum Perhutani dan menampung aspirasi para anggota kelompok tani terkait keluhan dan kesulitan para anggota kelompok tani dalam hal sosial ekonomi mereka. Adapun pemanfaatan aset-aset dalam tahapan dialog ini yaitu Pemanfaatan kapital manusia dalam tahap ini yaitu memanfaatkan tenaga ahli lokal khusus dalam mensukseskan penyampaian mengenai pengelolaan 
hutan kepada masyarakat desa hutan. Adanya keterbatasan masyarakat desa hutan yang rata-rata berpendidikan rendah menyebabkan dialog lebih banyak komunikasi satu arah Pemanfaatkan kapital sosial dalam tahap ini yaitu Tingkat kepercayaan masyarakat terhadap Perum Perhutani dan Kelompok Tani mempermudah terjadinya proses komunikasi antar pihak Pemanfaatkan kapital fisik dalam tahap ini yaitu Pertemuan formal setelah sosialisasi telag banyak menggunakan gubug kerja sebagai tempat dialog

- Pemanfaatkan kapital keuangan dalam tahap ini yaitu Swadaya masyarakat desa hutan dugunakan dalam memperlancar dialog antara Petugas Perum Pehutani dan TPM

- Dalam tahapan ini pemanfaatan kapital lingkungan tidak diperlukan karena kapital lingkungan berupa sumber daya hutan, air bersih, dan kondisi cuaca dan iklim diperlukan pada tahapan pelaksanaan kerjasamaDalam tahapan ini pemanfaatan kapital lingkungan tidak diperlukan karena kapital lingkungan berupa sumber daya hutan, air bersih, dan kondisi cuaca dan iklim diperlukan pada tahapan pelaksanaan kerjasama
Negosiasi merupakan proses tawar menawar antara Petugas Perum Perhutani dengan anggota kelompok tani sehingga mencapai kesepakatan antara kedua belah pihak. Setelah membahas hak-hak dan kewajiban Perum Perhutani dan anggota, selanjutnya pembahasan mengenai pembentukan kelembagaan.Adapun pemanfaatan aset-aset dalam tahapan negosiasi ini yaitu

- Pemanfaatan kapital manusia dalam tahap ini yaitu Petugas Perum Perhutani dan pendamping LSM memanfaatkan ketua kelompok - kelompok tani dan tenaga ahli lokal dalam merumuskan kesepakatan kerjasama antar pihak

- Pemanfaatan kapital sosial dalam tahap ini yaitu Masyarakat Desa Hutan cenderung memberi kepercayaan kepada Ketua Kelompok Tani, TPM dan tenaga akhli lokal untuk membangun jaringan dengan Petugas Perhutani dan investor

- Pemanfaatan kapital fisik dalam tahap ini yaitu Memanfaatkan sarana gubug kerja dengan segala fasilitasnya dimanfaatkan untuk penyelesaian kesepakatan kedua belah pihak

- Pemanfaatan kapital keuangan dalam tahap ini yaitu Swadaya masyarakat desa hutan dugunakan dalam memperlancar negosiasi

- Dalam tahapan ini pemanfaatan kapital lingkungan tidak diperlukan karena kapital lingkungan berupa sumber daya hutan, air bersih, dan kondisi cuaca dan

\section{Negosiasi}


iklim diperlukan pada tahapan pelaksanaan kerjasama.

\section{Aspek legal}

Aspek legal merupakan proses penandatangan perjanjian kerjasama para pihak yang telah disepakati dan disahkan oleh notaris, serta proses pembentukan kelembagaan LMDH. Adapun pemanfaatan aset-aset dalam tahapan aspek legal ini yaitu

- Pemanfaatan kapital manusia dalam tahap ini yaitu Memanfaatkan Pengurus Lembaga Masyarakat Desa Hutan dan KTH dalam penyusunan kesepakatan kedua belah pihak antara Perum Perhutani dan $\mathrm{MDH}$ Pemanfaatan kapital sosial dalam tahap ini yaitu Masyarakat cenderung memberikan kepercayaan kepada Pengurus LMDH dan ketua KTH dalam hal penandatangan surat perjanjian kerjasama

- Pemanfaatan kapital fisik dalam tahap ini yaitu Memanfaatkan sarana gubug kerja, ruang koperasi, sekertariat LMDH sebagai tempat pengesahan SPK

- Pemanfaatan kapital keuangan dalam tahap ini yaitu Swadaya masyarakat desa hutan dugunakan dalam memperlancar penyelesaikan penandatangan kesepakatan yang dituangkan dalam surat perjanjian kerjasama

- Dalam tahapan ini pemanfaatan kapital lingkungan tidak diperlukan karena kapital lingkungan berupa sumber daya hutan, air bersih, dan kondisi cuaca dan iklim diperlukan pada tahapan pelaksanaan kerjasama.

\section{Pelaksanaan}

Selanjutnya tahap kelima dalam kegiatan pembinaan masyarakat yaitu pelaksanaaan terhadap isi perjanjian kerjasama antara Petugas Perum Perhutani dan anggota kelompok tani. Dalam pelaksanaannya, masih ada beberapa anggota kelompok tani masih tidak konsisten terhadap kesepakatan dalam perjanjian kerjanjian kerjasama. Hal ini di tunjukkan beberapa anggota petani menanam sayuran. Dalam tahap pelaksanaan, dimana seharusnya anggota kelompok petami tersebut menanam tanaman keras yaitu kopi dan tanaman berkayu seperti kayu putih dan suren sesuai kesepakatan yang dituangkan dalam perjanjian kerjasama.

Adapun pemanfaatan aset-aset dalam tahapan pelaksanaan ini yaitu:

\section{Kapital Manusia}

Pemanfaatkan tenaga ahli lokal dalam hal masalah-masalah teknis pengelolaan hutan seperti menanam kayu, menanam kopi, cara pemilihan bibit yang baik, budidaya kopi, konservasi hutan, pemeliharaan, pemanenan, pengolahan dan pemasaran, Perum Perhutani 
melakukan pembinaan dan pelatihan kepada anggota, dan anggota memanfaatkan pelatihan tersebut untuk menambah keterampilan mereka

\section{Kapital Sosial}

Pemanfaatan pengurus LMDH dam KTH, dengan memberikan penyuluhan secara infomral kepada anggota mengenai pemeliharaan kopi, pembibitan, pemanenan, pengolahan, pemasaran

\section{Kapital Fisik}

Pemanfaatan sarana jalan raya di sekitar hurtan, masyarakat membuat jalan secara bersama-sama sehingga mempemudah proses pelaksanaan

\section{Kapital keuangan}

Pemanfaatan sarana jalan raya di sekitar hurtan, masyarakat membuat jalan secara bersama-sama sehingga mempemudah proses pelaksanaan digumakan untuk memperlancar pemanenan kayu dan kopi di lahan Perhutani

\section{Kapital Lingkungan}

Pemanfataan kapital lingkungan meliputi air bersih,tanah yang subur, Hutan. Dengan adanya hutan, mengelola hutan dan menanam kopi, kopi dijadikan sumber mata pencaharian mereka. Selain kopi memiliki nilai jual yang tinggi, kopi mampu menyerap air sehingga kelestarian hutan tetap terjaga dan kopi bisa tumbuh dibawah tegakan hutan karena kopi tidak boleh banyak terkena sinar matahari. Kalau dilihat dari aspek lingkungan lahan dan iklim mendukung budidaya kopi. Mewujudkan kelestarian hutan sekaligus kesejahteraan bagi si penggarap.

\section{Monitoring dan Evaluasi}

Tahap keenam dari kegiatan pembinaan masyarakat desa hutan yaitu monitoring dan evaluasi. Adapun pemanfaatan aset-aset dalam tahapan monitoring dan evaluasi ini yaitu

- Pemanfaatan kapital manusia dalam tahap ini yaitu Pemanfaatan tenaga ahli dan TPM dalam proses evaluasi

- Pemanfaatan kapital sosial dalam tahap ini yaitu Pemanfaatan pengurus LMDH dan KTH dalam monitoing

- Pemanfaatan kapital fisik dalam tahap ini yaitu Pemanfaatan sarana gubug kerja sebagai tempat tempat oertemuan formal maupun informal untuk memperlancar monitoring dan evaluasi Pemanfaatan kapital keuangan dalam tahap ini yaitu Pemanfaatan swadaya masyarakat untuk memperlancar proses monitoring dan evaluasi

- Dalam tahapan ini pemanfaatan 
kapital lingkungan tidak diperlukan karena kapital lingkungan berupa sumber daya hutan, air bersih, dan kondisi cuaca dan iklim diperlukan pada tahapanpelaksanaan kerjasama.

\section{Rencana Tindak Lanjut}

Tahap akhir dari kegiatan pembinaan masyarakat adalah rencana tindak lanjut. Pada tahap rencana tindak lanjut ini disusun atas dasar hasil monitoring dan evaluasi, khususnya kewajiban-kewajiban kedua belah pihak yang belum terlaksana. Adapun pemanfaatan aset-aset dalam tahapan rencana tindak lanjut ini yaitu

- Pemanfaatan kapital manusia dalam tahap ini yaitu Pemanfaatan tenaga ahli lokal dan TPM dalam pembahasan mengenai kewajiban-kewajiban kedua belah pihak yang belum terlaksana

- Pemanfaatan kapital sosial dalam tahap ini yaitu Pemanfaatan pengurus LMDH dan ketua kelompok tani pembahasan mengenai sharing yang seharusnya sesuai dengan kesepakan tang telag disepakati bersama Pemanfaatan kapital fisik dalam tahap ini yaitu Pemanafaatan sarana prasarana yang ada di desa Pulosari untuk memperlancar proses rencana tindak lanjut wadaya dan dana dari Perum Perhutani untuk mrmperlancar tahap rencana tindak lanjut

- Dalam tahapan ini pemanfaatan kapital lingkungan tidak diperlukan karena kapilingkungan berupa sumber daya hutan, air bersih, dan kondisi cuaca dan iklim diperlukan pada tahapan pelaksanaan kerjasama.

Berdasarkan hasil penelitian, masyarakat berpendapat bahwa Perum Perhutani belum secara optimal memberikan bantuan dalam bentuk financial (keuangan, bantuan modal atau investasi dalam bentuk uang), belum optimal dalam memfasilitasi LMDH dalam memperoleh sumber modal atau bantuan dari pihak ketiga. Hal ini ditunjukkan anggota kelompok tani masih kesulitan dalam hal proses pemanenan karena anggota kekurangan bibit dan pupuk sehingga mempengaruhi hasil panen, belum secara optimal melakukan penjagaan ketat dan melakukan peneguran karena masih ada beberapa anggota kelompok tani yang menanam sayur mayur dan tidak sesuai dengan perjanjian kerjasama yang telah disepakati.

\section{KESIMPULAN}

Berdasarkan uraian hasil penelitian dan pembahasan tentang PHBM melalui kegiatan pembinaan masyarakat ditinjau dari perspektif Asset Based Community Development diperoleh kesimpulan sebagai berikut:

1) Pelaksanaan kegiatan pembinaan masyarakat melalu tahapan sosialisasi, dialog, negosiasi, aspek legal, monitoring dan evaluasi, serta rencana tindak lanjut secara umum terlaksana dengan baik. 
Namun ada beberapa kelemahankelemahan yang perlu diperbaiki yaitu

a. Kurangnya partisipasi anggota kelompok tani

b. Beberapa kelompok tani masih belum konsisten terhadap isi Perjanjian Kerjasama

c. Anggota kelompok tani masih belum percaya sepenuhnya kepada koperasi

d. Anggota kelompok tani lebih banyak menjadi pendengar dan mempercayakan sepenuhnya kepada ketua kelompok dan LMDH (komunikasi satu arah)

e. Penjualan kopi masih bercabang (tidak satu pintu) sehingga Perum Perhutani sulit memnetukan sharing

2) PHBM telah dilaksanakan sesuai dengan pengembangan masyarakat berbasis aset. Asset Based berupa kapital manusia, kapital sosial, kapital fisik, kapital keuangan, dan kapital lingkungan telah dimanfaatkan pada setiap dalam kegiatan Pembinaan Masyarakat Namun ada beberapa aset yang belum optimal dimanfaatkan dalam tahapan pembinaan masyarakat desa hutan yaitu

a. Kurangnya upaya peningkatan kualitas sumberdaya manusia

b. Partisipasi anggota masih rendah

c. Kurangnya peran LMDH, KTH untuk meningkatkan kesadaran berkoperasi

d. koperasi belum dimanfaatkan oleh anggota sebagai media pemasaran, simpan pinjam anggota, modal

\section{DAFTAR PUSTAKA}

\section{A. Buku-buku}

Alfitri. 2011. Community Development: Teori dan Aplikasi. Yogyakarta: Pustaka Pelajar

Creswell, John W. 2010. Research Design Pendekatan Kualitatif, Kuantitatif, dan Mixed. Yogyakarta: Pustaka Pelajar

Green, Gary Paul \& Anna Haines. 2000. Asset Building and Community Development. United States

Huraerah, Abu. 2011. Pengorganisasian dan pengembangan masyarakat. Bandung:Humaniora

Hasbullah, Jousairi. 2006. Social Capital: Menuju Keunggulan Budaya Manusia Indonesia. Jakarta: MRUnited Press.

Ife, J \&Frank Tesoriero. 2008. Community Development: Alternatif Pengembangan Masyarakat di Era Globalisasi. Yogyakarta: Pustaka Pelajar

Moleong, Lexy J. 2007. Metodologi Penelitian Kualitatif. Bandung: Rosda

Miles, Mathew B. Dan A. Michael Huberman. 1992. Analisis Data Kualitatif Buku Sumber tentang Metode-Metode Baru. Jakarta: Universitas Indonesia (UI-Press)

Sugiyono. 2009. Metode Penelitian Kuantitatif Kualitatif dan $R \& D$. Bandung: Alfabeta

Silalahi, Ulbert. 1999. Metode dan Metodologi Penelitian. Bandung: Bina Budhaya 
Usman, Husaini \& Purnomo Setiady Akbar. 2011. Metodologi Penelitian Sosial. Jakarta: PT. Bumi Aksara

Tjahja Djajadiningrat, Surna dkk . 2003. Akses Peran Serta Masyarakat lebih jauh memahami Community Development. Jakarta: Indonesia Center for Sustainable Development (ICSD)

\section{B. Dokumen-dokumen}

Perum Perhutani- Pedoman Pengelolaan Sumber Daya Hutan Bersama Masyarakat (PHBM)- Desember 2009

Perum Perhutani- Pedoman Kelola Sosial Desember 2009

Kesejahteraan Sosial- Buku panduan pelaksanaan praktikum pengembangan masyarakat

Media Persaki Volume 12:2009

Perum Perhutani- Implementasi Pengelolaan Hutan Bersama Masyarakat, Juli 2008

\section{Sumber Lain}

http://perumperhutani.com

http://dkp.kerincikab.go.id

http://repository.usu.ac.id/bitstream/123456789 /18483/4/Chapter\%20II.pdf

http://www.sociotyentrepreneur.com/readblog.php?id=21

http://www.damandiri.or.id/file/yuliaistanahunai rbab4.pdf

http://repository.upi.edu/operator/upload/s mbs 011611 chapter3.pdf

http://blogs.unpad.ac.id/rsdarwis/?p=8 